9. The Federal Law from 28 December 2013 N 400-FZ “On Insurance Pensions” (ed. by 29 December, 2015) (available in Russian at: URL: http://base.garant.ru/)

10. Vladimir Nazarov, Sergei Sinelnikov-Murylev. A Strategy for Reforming the Russian Pension System//Economic policy, - No 3, 2009 (available at http://papers.ssrn.com/sol3/papers.cfm?abstract_id=2111085)

11. Yuldashev R.T., Odinokova T.D. Risky life insurance: products of mass consumption // Strakhovoe delo. 2015. № 12 (273). P. 48-60.

DOI: http://dx.doi.org/10.20534/EJEMS-17-1-53-55

Sharku Gentiana,

University of Tirana, Faculty of Economics, Albania

E-mail:gentasharku@yahoo.com

\title{
Investment Alternatives for Individual Investor in Albania
}

Abstract: During the communism period, characterized by centralized economy, the sole investing alternative for population has been depositing the money in the sole financial saving institution — Institute of Savings and Insurance. After twenty seven years of free market economy, financial system in Albania is a bank based system. Therefore, bank products are the primary and the classic investment alternative for the major part of population. Are any other opportunities for investment by Albanian investors? This article aims to point the alternatives used by individual investors in Albania and the reasons for which using such alternatives.

Keywords: bank deposit, treasure bill, investment fund.

\section{Introduction}

After the transformation of the economy from the centralized to open free market economy (in 1991), during the last two decades the financial system has been radically changed. Until 1990, the financial system has been composed of the Central Bank (functioning as a state bank and as a commercial bank as well), one depositary institution (Institute of Savings and Insurance), and one bank (Agriculture Bank, which had the monopoly of crediting the agriculture enterprises and cooperatives). All have been state owned institutions. No other financial institutes existed. Only after 1991, the foreign capital entered in the banking sector. During the first decade of transformation process (1991-1999), other commercial banks have been established and several credit unions have been opened. Therefore the formal investing alternatives have been very few. During this period, the pyramidal schemes have been designed, which provided extremely high interest rates. The most part of the Albanian citizen's savings was invested in these informal institutions. After their closure in 1998, many of Albanian investors have lost their money. It was a very disappointed investment experience for Albanian investors. Only after 2000 the real transformation of the financial system began: the existing state owned financial institutions have been privatized, and new financial institutions have been established. In the end of 2015, the financial system of Albania is composed of the following institutions, with respective share of the actives to total financial system actives:

- Banking sector - 90.13 percent;

- Investments funds - 4.64 percent;

- Insurance companies - 1.88 percent;

- Other financial institutions (loan and credit institutions, union credits, leasing and factoring companies, private pension funds) -3.35 percent.

The financial system in Albania is supervised by two authorities: Bank of Albania and Albanian Financial Supervisory Authority. The legislation regarding the financial sectors has been radically changed and improved over years. There is no stock exchange in Albania. It has been opened in 1996 and it has been closed down in 2014. The absence of the stock exchange explains the few investment alternatives. Despite the various financial institutions operating in Albania, the most used investment alternatives from Albanian citizens are: banking deposits, government securities and investments funds. The aim of the article is to describe the investment alternatives used by the Albanian citizens, in order to point out the characteristics of Albanian individuals' investment. The article is organized in five sections. After the introduction, the next section describes the banking deposits. 
The third and fourth sections describe respectively the treasury bills and investment funds. The conclusions are presented in the last section.

\section{Bank deposits}

Opening of a saving account in a commercial bank is the traditional investment for the Albanian investor. The only investment possibility during the communism period (before 1991) has been the deposits in the commercial bank. Therefore, Albanian families have traditionally saved their money in the saving accounts. After the liberalization of the banking sector, the private and foreign capital entered in Albania. Actually there are 16 commercial banks operating in Albania. Customer's deposits constitute the most important and stable source of financing for the Albanian banking system, sharing 83.5 percent of total liabilities (2015). Households' deposits remain the main base of banking system's deposits with a share of $85 \%$ of total deposits.

In December 2015, total value of deposits in the system amounted ALL 1.1 trillion, with an annual growth of $2.8 \%$. The share of domestic currency to total deposits was about 49 percent. Maturity structure recently is shifted to short-term maturities, as the current accounts and time deposits shrank upon the impact of the continuous lowering of the interest rates. In December 2015, ten largest depositors accounted for $4.5 \%$ of total banking system's deposits. Four largest banks of the system shared about 60 percent of the system total deposits. Two of them have been state owned banks which have been privatized. Although the second one (Raiffeisen Bank) has almost the lowest deposit interest rates, it shares about 22 percent of the system total deposits. This is due to the fact that the population savings before 1990 has been monopoly of the Institute of Savings and Insurance. In 1991 this institution has been transformed in the Saving Bank (today Raiffeisen Bank). Therefore the Raiffeisen Bank has inherited large amounts of deposits.

Following the reduction of the economic growth in Albania, the interest rates of the bank deposits have been decreased. In 2009, the deposit interest rate (12 monthly ALL deposit) was 6.75\%. In 2013 it was $4.17 \%$, and in 2014 it has been decreased in $1.51 \%$. The reduction of interest rates has been continued in 2015 (1.46\%). The interest rates during the last years have been even lower than inflation rates, resulting in a real negative rate of return for depositors.

After the collapse of pyramidal schemes and due to the low interest rates of bank deposits, Albanian individual investors have search for risk-free short term investment alternatives, such as Treasury bills.

\section{Treasury bills}

After the collapse of pyramidal schemes in 1998, the Albanian individual investors have been more prudent in investing their money. They were more unconfident with investing alternatives other than banking deposits. However, they began to look for investing alternatives, which were considered risk free. Since 1994, government of Albania has used treasury bills and bonds to borrow funds from the public and financial institutions. Treasury bills are attractive to investors because they are backed by the government and therefore they are free of default risk. Another attractive feature of treasury bills is their liquidity, due to their short maturity. Existing treasury bills can be sold in the secondary market through dealers licensed by Albanian Financial Supervisory Authority, who profit by purchasing the bills at a slightly lower price than the price at which they sell them.

Treasury bills in Albania are sold to individual and institutional investors. Institutional investors include the Bank of Albania, commercial banks, insurance companies, private pensions, investment funds etc. As treasury bills are risk-free securities, they should provide the lowest yield in the market. But at contrary, the yield provided from the investments in Treasury bills has been historically greater than the bank deposit interest rates. In 2009, 2013, 2014 and 2015, the yield on Treasury bills (with maturity of 12 months) has been respectively 9.14\%, 3.66\%, 3.33\% and 3.59\%. This "paradox" is due to the fact that commercial banks invest a large portion of their liquidities in treasury bills, and as they have a lot of liquidity, they are not encouraged to attract more household's deposits. As result, the commercial banks have decreased the deposit interest rates, which has been even lower than the yield provided by the Treasury bills. The low deposit interest rates have oriented the Albanian individual investors toward Treasury bills, which offered them security. Therefore the participation of individuals in Treasury bills auctions has been increased as they were the most secured investment, providing higher interest rates than bank deposits. But the sharp continuous reduction of interest rates for bank deposits and treasury bills, has encouraged the Albanian individual investors to reallocate their savings toward other new investments, such as investments funds.

\section{Investment funds}

Supervision of investment funds is exercised by Albanian Financial Supervisory Authority. The investment fund market in Albania started operation in 2012. It has been greatly expanded, ranking the second largest market after the banking market. In 2012 the ratio of in- 
vestment funds assets to total financial system assets was $1.26 \%$, while in 2015 the ratio is increased to $4.64 \%$. The expansion dynamics of these funds show that domestic investors are interested in new saving and investment products. During 2015, two investment funds exercised their activity in the Investment Fund's market: the "Raiffeisen Invest Euro" dominated in Euro and "Raiffeisen Prestig;" dominated in All (Albanian leke). Both funds are collective undertakings with public offering established by Raiffeisen Invest sh. a. which is a management company for pension funds and collective investment undertakings. The funds invest mainly in government bonds, which consist $70 \%$ of fund assets. About $99.99 \%$ of fund members are individual investors. The minimum investment into the "Raiffeisen Prestigj" fund is All 5000. The subsequent investment amount is at least All 1000. During the period of initial offering of units in the fund, the price of issue is All 1000. After the initial offering, the price of unit is a uniform price equal to the fund net asset value per unit, calculated on the basis of the market price of all securities in the portfolio. This kind of investment provides liquidity as the unit holders may request at any time the redemption of their units, which has to be satisfied within seven days. In 2015, net assets value per unit of both investment funds is increased by $4.3 \%$ in comparison with 2014. "Raiffeisen Presitege" fund has the largest increase by $6.8 \%$, while
"Raiffeisen Invest Euro" asset value per unit is increased by only $0.11 \%$.

Individual who have invested their money in investment funds have provided higher rates of return than investments in bank deposits or treasury bills. But they have to know that they are exposed to several risks, such as market risk, credit risk and liquidity risks.

\section{Conclusions}

Financial system offers a variety of investing alternatives for individual investors. As the banking system assets in Albania consist 90 percent of the total financial system assets, the bank products constitute the primary investing alternative for Albanian individuals. Bank deposits are considered as a traditional investment form for Albanian individual investor, inherited from the communism. The second investing alternative is investing in treasury bills, which historically have offered higher return rates than bank deposits. Treasury bills, which are risk-free investments, are taken in consideration as a good investment opportunity, especially for the Albanian investors disappointed by the pyramidal schemes. However, during the last years, when the interest rates have recorded their minimal values, Albanian investors have started to reallocate their savings to other alternatives, more risky, such as investment funds. Investment funds are attracting the individual investors due to high return rates and their liquidity.

\section{References:}

1. URL: http: www.bankofalbania.org - Official webpage of Bank of Albania.

2. URL: http: www.amf.gov.al - Official webpage of Albanian Financial Supervisory Authority.

3. URL: http: www.raiffeisen-invest.al 